\title{
Short Communication: Bird correlations with waste in Muara Gembong, West Java, Indonesia
}

\author{
SELSA ARTIKA AYUJAWI ${ }^{1, \boldsymbol{v}}$, NURUL LAKSMI WINARNI ${ }^{1,2}$, DIMAS HARYO PRADANA ${ }^{1}$ \\ ${ }^{1}$ Department of Biology, Faculty of Mathematics and Natural Sciences, Universitas Indonesia. Jl. Lingkar UI, E Building UI Campus, Depok 16242, \\ West Java, Indonesia. Tel.: +62-21-7270163, Fax.: +62-21-78829010, ‘email: selsaayujawi@gmail.com \\ ${ }^{2}$ Research Center for Climate Change, Universitas Indonesia, UI Campus, Depok 16242, West Java, Indonesia.
}

Manuscript received: 12 March 2021. Revision accepted: 25 August 2021.

\begin{abstract}
Ayujawi SA, Winarni NL, Pradana DH. 2021. Short Communication: Bird correlations with waste in Muara Gembong, West Java, Indonesia. Biodiversitas 22: 3872-3879. The existence of waste in Muara Gembong can potentially affect bird abundance because organic waste can be a source of bird food, while inorganic waste can cause changes in habitat structure. This study aimed to (i) determine bird species that have a high abundance near the trash, and (ii) determine the correlation between waste concentration and the relative abundance of birds. The study was conducted in June 2020 in Pantai Mekar and Muara Blacan areas, Muara Gembong, West Java. Bird observation was carried out using exploration method and the relative abundance of the bird was determined based on encounter rates. The data collection and calculation of waste concentration were carried out following the NOAA protocol. The Spearman correlation test was carried out between the abundance of each bird species and the concentration of waste. Our results suggested that 26 species of birds in Muara Gembong were found near trash and 24 species have negative correlations to inorganic waste. The Javan munia (Lonchura leucogastroides) and Great egret (Egretta alba) were the most abundant species living near the trash with encounter rates of 39.13 and 38.89, respectively. Moreover, the concentration of inorganic waste has a significant negative correlation to the relative abundance of Cerulean kingfisher (Alcedo coerulescens), Spotted dove (Streptopelia chinensis), and Sunda collared dove (Streptopelia bitorquata). Based on these findings, inorganic waste in Muara Gembong can significantly reduce the abundance of birds in the long term because the pile of inorganic waste may cause damage to the mangrove forest, which is a bird habitat.
\end{abstract}

Keywords: Birds, coastal zone, mangrove, Muara Gembong, relative abundance, Spearman correlation, waste

\section{INTRODUCTION}

Muara Gembong is an important habitat to waterbirds, including the Endangered Milky stork (Mycteria cinerea). Muara Gembong was declared as an Important Bird Area (IBA) because it is a habitat to endangered species and accommodates $\geq 1 \%$ of the global population of a bird species during the mating or migration season (Birdlife International 2021). However, Muara Gembong is one area that is susceptible to waste pollution because it is located on the coast. This is because the coast accommodates the load of garbage carried from the upstream of the river and continues to accumulate to the estuary. Muara Gembong is the place where the Citarum River and many other tributaries empty directly to the Java Sea. Moreover, trashes in the sea are often carried by the wind and waves until they are stranded on the coast, including the Muara Gembong mangrove area.

The existence of waste can affect bird abundance in Muara Gembong because waste can be a source of disease by spreading viruses and pathogens (Jurinovic et al. 2014), and endanger the birds in many other ways. There are cases where birds swallow plastic waste which is mistaken for food due to its similar looks. Ingesting plastic waste creates a feeling of fullness so that the bird stops eating and affects their buoyancy while diving, which can lead to death (Codina-García et al. 2013). Fish hook waste can also be dangerous to birds when swallowed by birds forage around fishing boats. Ingesting metal-based waste has the risk of causing heavy metal poisoning (Liu et al. 2015). Moreover, piles of inorganic waste can cause the degradation of mangrove forests (van Bijsterveldt et al. 2021). If mangrove vegetation is lost, birds will also lose their food source, shelter, and nest, particularly for specialist birds such as waterbirds that can only use resources in the mangrove ecosystem. Habitat loss affects the abundance of bird (Durães et al. 2013).

Although many studies have shown that waste causes negative effects, some other studies have shown that waste increases population abundance and reproductive success in birds because organic waste can be an alternative source of natural food (Steigerwald et al. 2015; Torres-Mura et al. 2015). This indicates that the presence of waste can have different impacts. However, many studies do not describe the condition and characteristics of waste in detail (Plaza and Lambertucci 2017). Therefore, the specific condition of waste (such as type and size) needs to be recorded to understand its impact on the environment in more detail.

Correlation studies between waste and bird communities are still quite rare in Indonesia and have never been carried out in Muara Gembong. Therefore, it is necessary to study the effect of waste on the bird's abundance in Muara Gembong to understand the impact of waste in the environment, particularly on bird communities. In addition, the data obtained will be expected to be a consideration for better waste 
management. Thus, the objectives of this study were (i) to determine the bird species that have a high abundance near the trash, and (ii) to determine the correlation between waste concentration and the relative abundance of bird species in Muara Gembong.

\section{MATERIALS AND METHODS}

\section{Study area}

Field data collection was carried out in Muara Gembong, Bekasi, West Java, Indonesia. The research area of 422 ha was selected based on the presence of birds and trash by considering accessibility to the observation points. The area was located between the mangrove ecotourism area of Pantai Mekar $\left(06^{\circ} 01\right.$ '28 "S, $\left.106^{\circ} 59^{\prime} 48^{\prime \prime} \mathrm{E}\right)$ and the mangrove forest of Muara Blacan $\left(06^{\circ} 01\right.$ ' 31 "S, $107^{\circ}$ $\left.01^{\prime} 23^{\prime \prime} \mathrm{E}\right)$. Muara Gembong is a mangrove habitat with major vegetations include Rhizophora sp., Avicennia sp., Sonneratia sp., Bruguiera sp. and Nypa fruticans. There were 13 observation points including mangrove forests, fishponds, and settlements (Figure 1).

\section{Procedures}

\section{Bird data collection}

The bird observation was carried out using the exploration method (Sitanggang et al. 2020). The observation points were determined based on the conditions in which (i) birds were found in the trash- contaminated locations, and (ii) birds were found in other locations free of the trash. This was done to ensure whether a bird species are present in both conditions, or only use one of them. Seven sites were trash-contaminated while six sites were trash-free areas. Therefore, there were 13 observation points in total with distance between each point is $200-800 \mathrm{~m}$. Bird data was collected once a week for 3 weeks in June 2020 during 06:00-10:00 in Western Indonesia Time (WIB). The time spent for bird counting at each point was between 45 to 60 minutes, different amounts of time were used to prevent same encounter rates values (ER) to minimize results bias on Spearman rank test (because the same ER values will be marked as the same rank). Both visual and auditory signs of birds were used for detection. Therefore, a bird's field guide book by MacKinnon et al. (2010) as well as supporting websites such as Xeno-canto (www.xeno-canto.org) and Coneix el riu (coneixelriu.museudelter.cat) were used to identify the species of birds found during observation. Bird species, number of individuals, and bird activities were recorded and then each species were categorized according to their size and habitat utilization. The categorization for each species was following the published article related to IMBCI (Index of Marsh Bird Community Integrity). The bird size was classified into 3 groups; small $(<15 \mathrm{~cm})$, medium $(15-30 \mathrm{~cm})$, and large $(>30 \mathrm{~cm})$. The birds that were able to utilize a wide range of habitat types were considered "generalists", while birds with specific habitat criteria were grouped into "specialists".
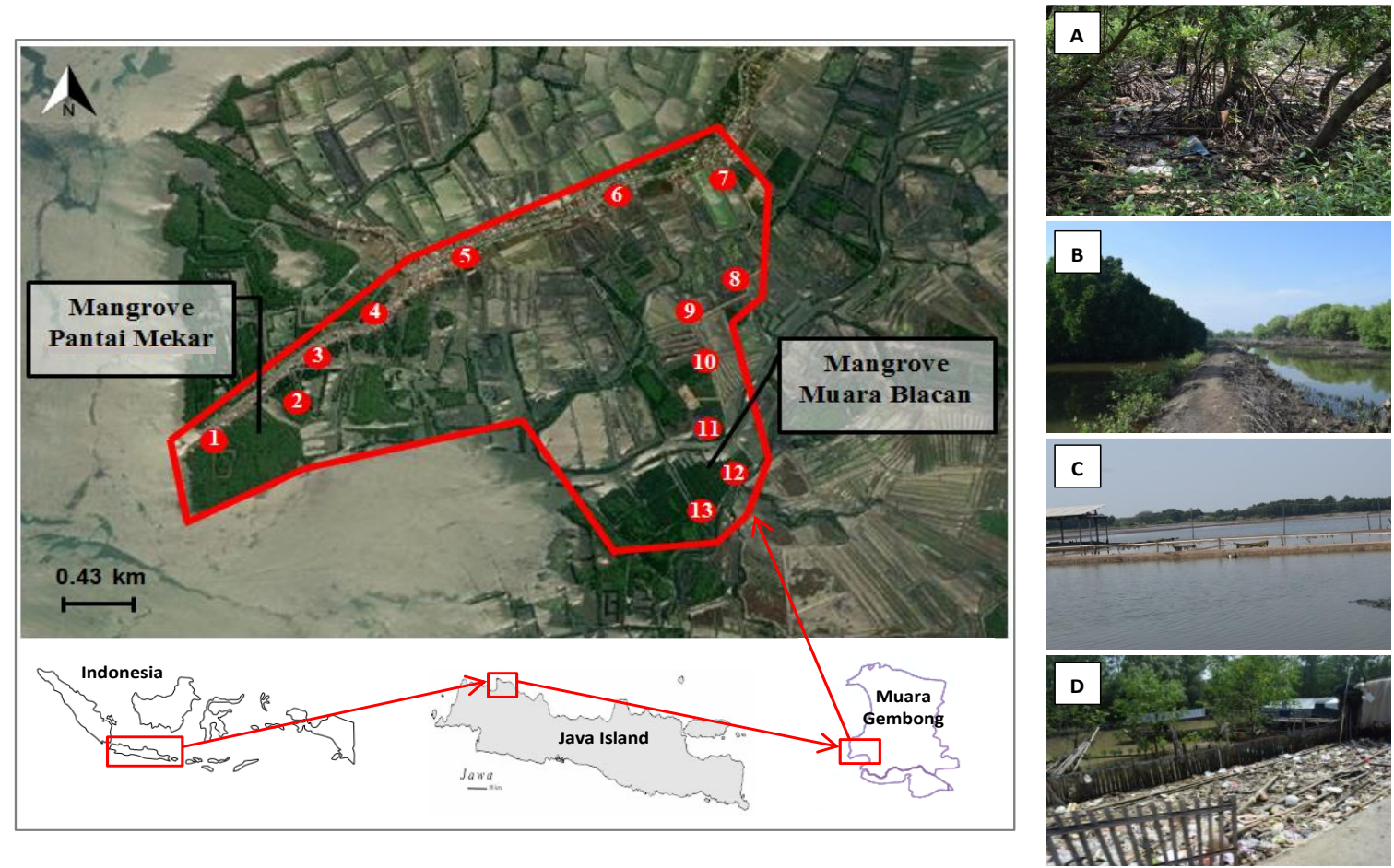

Figure 1. Location of observation points in the study in Muara Gembong, West Java, Indonesia: A. Mangrove forest, B. MangroveFishpond, C. Fishpond, D. Settlement 


\section{Habitat data collection}

The habitat conditions were recorded at each birdwatching point within a 10 -meter radius. The 13 sites consisted of 4 different habitat types; mangrove forest, mangroves-fishpond, fishpond, and settlement. The parameters recorded were the number of trees $(\mathrm{dbh}>10$ $\mathrm{cm}$ ), dominant tree species, canopy cover, and water salinity. Canopy cover was measured with the Canopeo apps (https://canopeoapp.com/) by shooting perpendicular to the sky in four different cardinal directions and the values obtained were then averaged. The water salinity was measured at each point by a refractometer with three times of repetition.

\section{Waste data collection}

Waste data were recorded at each bird observation point within a 10 meter radius $\left(314 \mathrm{~m}^{2}\right)$. The presence of waste was recorded in detail by adopting a method developed by the NOAA (National Oceanic and Atmospheric Administration) (Lippiatt et al. 2013). The waste data collection was carried out directly with the naked eyes or assisted by binoculars if the waste location was not possible to be observed closely. The parameters recorded were the amount, type, and size of the trash. The trash size was categorized as small $(2.5-30 \mathrm{~cm})$ or large $(>30 \mathrm{~cm})$. Thus, the minimum trash size that recorded was $2.5 \mathrm{~cm}$. Waste type categorization was done based on the visual, olfactory, or tactual observations. Detailed categorization of waste types was referred to the NOAA data sheet (Lippiatt et al. 2013), modifying the organic waste section.

\section{Data analysis}

The relative abundance of the bird was calculated using the encounter rates formula following Bibby et al. (2000) (Equation 1).

Encounter rates $=\frac{\text { total individual of each bird species }}{\text { total observation hour }} \times 10$

The concentration of waste was calculated at each observation point following the formula below (Lippiatt et al. 2013) (Equation 2).

$$
\text { Concentration of waste }=\frac{\text { number of macro debris items observed }}{\text { total area of observation }\left(\mathrm{m}^{2}\right)}
$$

The Spearman rank correlation test with formula referred to Xiao et al. (2015) was conducted using SPSS to determine the relationship between the waste and bird abundance. Although the study focused on the correlation between waste and birds, other environmental parameters were analyzed to minimize interpretation bias. Therefore, a path analysis was carried out to see how much influence the waste and other habitat parameters had on bird abundance. The results of the path analysis are presented in the form of a path diagram. Path analysis was carried out using SPSS.

\section{RESULTS AND DISCUSSION}

\section{The relative abundance of birds}

We recorded 29 bird species that consist of 15 generalists, 9 facultative, and 5 specialists. The bird species with the highest abundance near the trash were the Javan munia (Lonchura leucogastroides) and the Great egret (Egretta alba) with encounter rates of 39.13 and 38.89, respectively. The genus Lonchura was reported to have a high tolerance of anthropogenic disturbance and E. alba has an opportunistic foraging behavior (Renken et al. 2016; Zhou et al. 2020). The two species often utilize resources around areas contaminated with waste.

During observations, we found that three species, the Javan sparrow (Lonchura oryzivora), Milky Stork (Mycteria cinerea), and the Sacred kingfisher (Todiramphus sanctus) were always recorded at points where there was no trash. This is because the Milky Stork was tended to be very sensitive to habitat disturbance (Aziz et al. 2015). Although the Javan sparrow was only found in locations with no trash, this did not indicate that the Javan sparrow is avoiding trash because the genus Lonchura is tolerant of habitat change (Zhou e al. 2020).

Based on encounter rates, the Purple heron (Ardea purpurea), the Pacific reef heron (Egretta sacra), the Malaysian pied fantail (Rhipidura javanica), and the Collared kingfisher (Todiramphus chloris) were classified as "frequent" near the trash. Meanwhile, other species (except the Javan sparrow, the Milky stork, and the Sacred kingfisher which have an encounter rate value of 0.00 ) were categorized as "common" near the trash (Figure 2).

\section{Waste details}

The study area was dominated by plastic waste $(81.47 \%)$, followed by processed wood waste $(7.50 \%)$ and rubber waste $(7.39 \%)$. Glass, cloth/fabric, metal, and organic waste were less than $2 \%$ (Figure 3 ). The majority of plastic waste was found in the form of fragments, food wrappers, and straws, while rubber waste was mostly found in the form of flip-flops. There were 47 large trashes $(>30 \mathrm{~cm})$ from a total of 1813 debris at all observation points. The wreck of a wooden boat at observation point 1 was the biggest waste in size.

According to Table 1, there was no trash observed in the pond area. This is because Muara Gembong always experiences tidal flooding due to sloping topography, which is suspected to cause trash in open habitats to be carried away by currents and trapped between mangrove roots. The amount of trash that is stuck in mangrove roots increases over time (accumulated). Therefore, amount of trash in the mangrove forest habitat is very high. Meanwhile, human activities in residential areas also produce high amount of domestic trash (Viljoen et al. 2021).

The highest waste concentration was at observation point 1 (2.57 items $\left./ \mathrm{m}^{2}\right)$, followed by point 5 (1.47 items $\left./ \mathrm{m}^{2}\right)$ and point $4\left(0.67\right.$ items $\left./ \mathrm{m}^{2}\right)$. The concentration of waste at observation point $3,6,11$, and 12 were $0.38,0.33$, 0.25 , and 0.10 items $/ \mathrm{m}^{2}$, respectively. Meanwhile, observation points 2, 7-10, and 13 were areas free of trash (Figure 4). 
Table 1. Waste composition details in each habitat type

\begin{tabular}{clcccccccc}
\hline Observation & \multirow{2}{*}{ Habitat Type } & \multicolumn{7}{c}{ Number of Trash } \\
\cline { 3 - 8 } Points & & Plastic & Metal & Glass & Rubber & Lumber & Fabric & Organic & Total \\
\hline 1,11 & Mangrove forest & 710 & 9 & 11 & 84 & 57 & 14 & 2 & 887 \\
$2,3,12,13$ & Mangroves-fishpond & 125 & 3 & 2 & 7 & 12 & 2 & 0 & 151 \\
$7,8,9,10$ & Fishpond & 0 & 0 & 0 & 0 & 0 & 0 & 0 & 0 \\
$4,5,6$ & Settlement & 642 & 5 & 3 & 43 & 67 & 11 & 4 & 775 \\
\hline
\end{tabular}

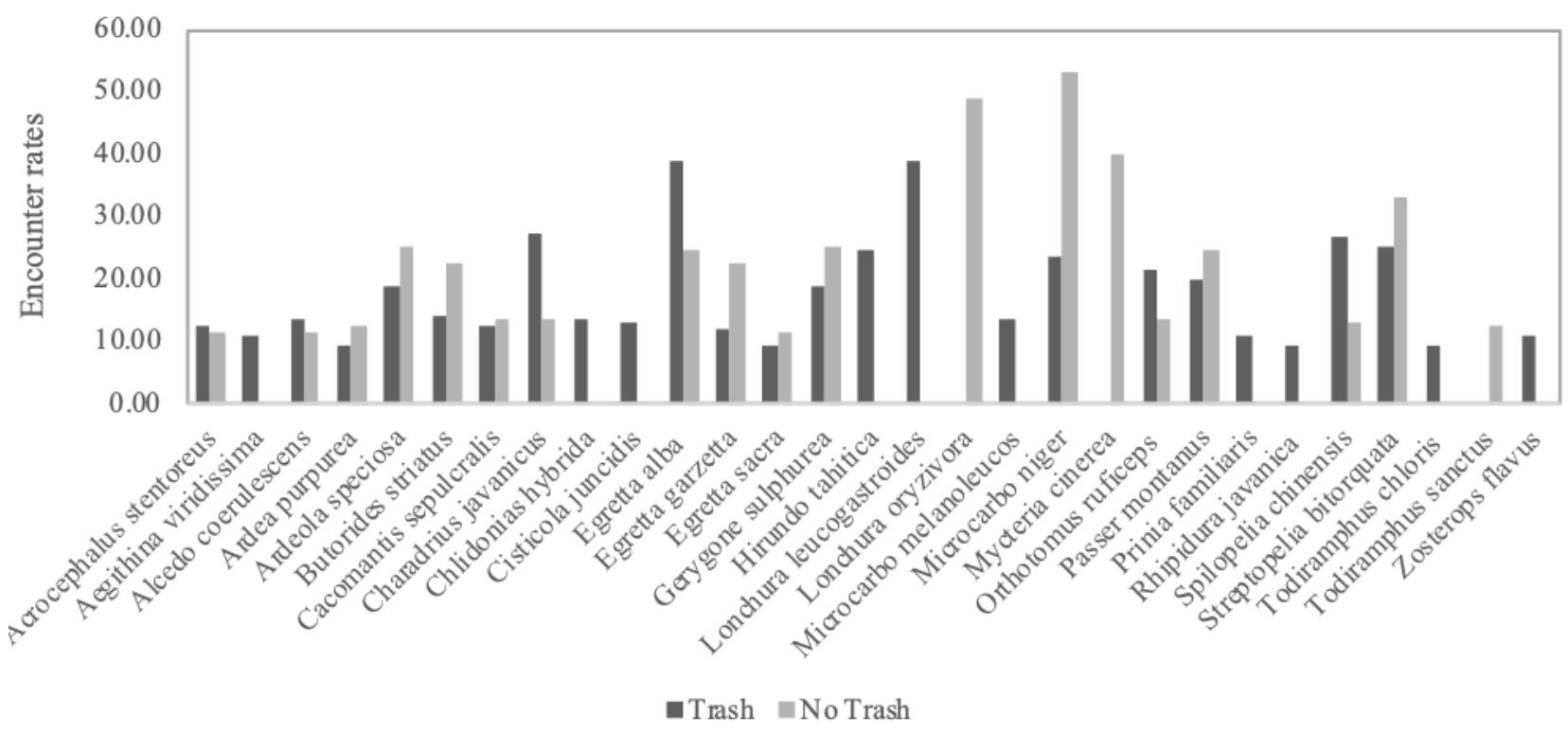

Figure 2. Encounter rate values and abundance categories of each bird species

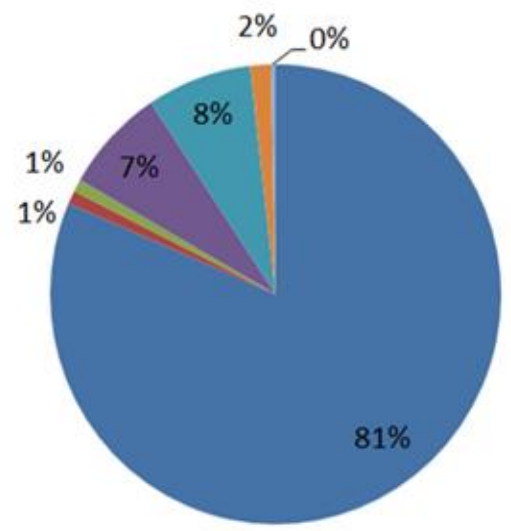

Waste Composition

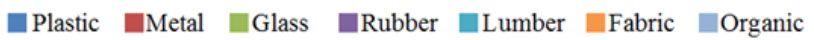

Figure 3. Waste composition in Muara Gembong, Indonesia

\section{Correlation between waste and birds}

Based on the Spearman rank correlation test (Table 2), the concentration of inorganic waste was significantly negatively correlated with the encounter rate of the Cerulean kingfisher (Alcedo coerulescens). This was
Concentration of Waste

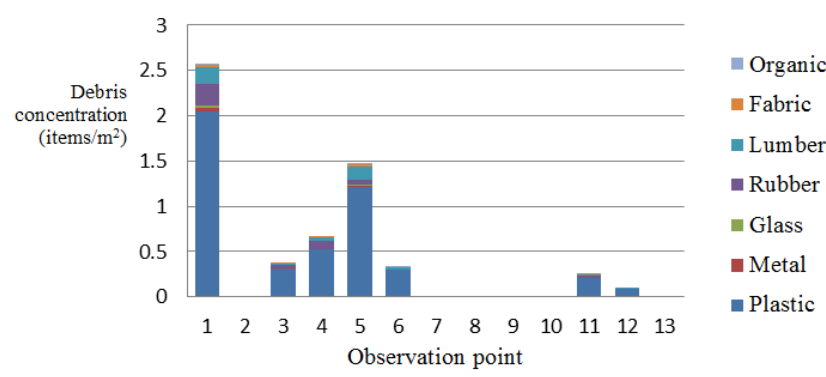

Figure 4. Waste concentration in Muara Gembong at each observation point

because the Cerulean kingfisher is a specialist bird that is sensitive and difficult to adapt to environmental changes (Chawaka et al. 2017). In addition, the Spotted dove (Spilopelia chinensis) and the Sunda collared dove (Streptopelia bitorquata) were also have a significant negative correlation with inorganic waste. These results are consistent with the research of Zhang et al. (2015) who found that there was a significant decrease in relative abundance on Streptopelia sp. at locations exposed to inorganic waste because inorganic waste can reduce the 
availability of seeds as a diet for the doves (Zhang et al. 2015).

In addition, the types of organic waste found in the field (such as fruit seeds and eggshells) were small in number and were usually inedible by birds. Thus, the correlation test results toward the concentration of organic waste tend to be insignificant because those organic wastes were neither a food source for birds nor causing significant environmental changes.

Although not significant, 24 bird species (82.8\%) negatively correlated their relative abundance and inorganic waste concentration, and only $17.2 \%$ had a positive correlation. Furthermore, 10 species of birds (34.5\%) had a positive correlation toward organic waste but were not statistically significant. These results indicated that some bird species may be able to use areas with organic waste for foraging, while the presence of inorganic waste is likely to give an impact on the bird abundance. Birds such as Cattle egret was reported to forage for organic waste at refuse dumps, such as fish fragments and flies (Annorbah and Holbech 2012). On the other hand, plastics and other inorganic waste will cover surface water which will entangle and frighten the birds (Ryan 2018; Tan et al. 2012). This was consistent with previous studies which reported that organic waste increased the relative abundance of some bird species while inorganic waste decreased the relative abundance of birds (Zhang et al. 2015; Plaza and Lambertucci 2017).

\section{Path analysis}

On average, the overall habitat has water salinity 5.72 ppt with average canopy cover 16.81. Mangrove forest has the most dense canopy cover while fishponds have the lowest canopy cover (Table 3 ). Based on path analysis (Figure 5), the presence of waste affects bird abundance both directly and indirectly through changes in habitat conditions. Habitat conditions were more influenced by inorganic waste, while bird abundance was more affected directly by organic waste. Organic and inorganic waste affects habitat conditions by $46.9 \%$. The presence of waste together with habitat conditions affects the abundance of birds by $20.7 \%$.

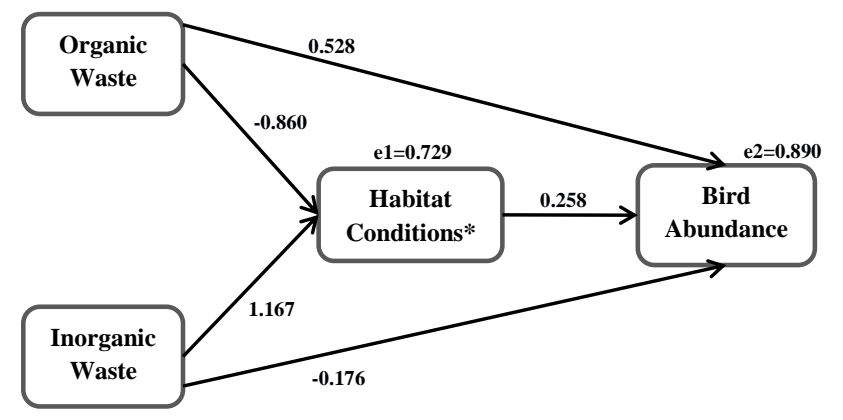

*) Canopy cover, salinity, and number of trees

Figure 5. Influence of environmental parameters on bird abundance using path analysis

Table 2. Results of the Spearman correlation test between the relative abundance of each bird species and concentrations of inorganic and organic wastes

\begin{tabular}{|c|c|c|c|c|}
\hline \multirow{2}{*}{ Species } & \multirow{2}{*}{ Size } & \multirow{2}{*}{ Habitat use } & \multicolumn{2}{|c|}{ Concentration of Waste } \\
\hline & & & Inorganic & Organic \\
\hline Acrocephalus stentoreus & Medium & Generalist & -0.312 & -0.429 \\
\hline Aegithina viridissima & Small & Generalist & -0.408 & -0.338 \\
\hline Alcedo coerulescens & Small & Specialist & $-0.733 *$ & -0.429 \\
\hline Ardea purpurea & Large & Facultative & -0.418 & -0.106 \\
\hline Ardeola speciosa & Large & Facultative & -0.470 & -0.126 \\
\hline Butorides striatus & Large & Facultative & -0.140 & -0.174 \\
\hline Cacomantis sepulcralis & Medium & Generalist & -0.436 & -0.429 \\
\hline Charadrius javanicus & Small & Facultative & -0.031 & 0.375 \\
\hline Chlidonias hybridus & Medium & Specialist & 0.408 & 0.676 \\
\hline Cisticola juncidis & Small & Generalist & -0.668 & -0.147 \\
\hline Egretta alba & Large & Facultative & 0.147 & 0.477 \\
\hline Egretta garzetta & Large & Facultative & -0.274 & -0.159 \\
\hline Egretta sacra & Large & Facultative & -0.109 & 0.071 \\
\hline Gerygone sulphurea & Small & Generalist & -0.109 & 0.071 \\
\hline Hirundo tahitica & Small & Generalist & -0.045 & -0.025 \\
\hline Lonchura leucogastroides & Small & Generalist & -0.204 & 0.225 \\
\hline Lonchura oryzivora & Small & Generalist & -0.577 & 0.000 \\
\hline Microcarbo melanoleucos & Large & Facultative & 0.408 & 0.676 \\
\hline Microcarbo niger & Large & Facultative & -0327 & -0.429 \\
\hline Mycteria cinerea & Large & Specialist & -0.577 & -0.283 \\
\hline Orthotomus ruficeps & Small & Generalist & -0.592 & -0.429 \\
\hline Passer montanus & Small & Generalist & -0.082 & 0.500 \\
\hline Prinia familiaris & Small & Generalist & -0.134 & 0.000 \\
\hline Rhipidura javanica & Medium & Generalist & 0.612 & 0.450 \\
\hline Spilopelia chinensis & Medium & Generalist & $-0.791 * *$ & -0.506 \\
\hline Streptopelia bitorquata & Medium & Generalist & $-0.694 *$ & -0.506 \\
\hline Todiramphus chloris & Medium & Specialist & 0.612 & 0.450 \\
\hline Todiramphus sanctus & Medium & Specialist & -0.577 & -0.283 \\
\hline Zosterops flavus & Small & Generalist & -0.408 & -0.338 \\
\hline
\end{tabular}

Note: * Correlation is significant at the 0.05 level. $* *$ Correlation is significant at the 0.01 level 
Table 3. Summary of habitat conditions, number of bird species and the encounter rates of birds at each observation point

\begin{tabular}{|c|c|c|c|c|c|c|c|}
\hline $\begin{array}{c}\text { Observation } \\
\text { point }\end{array}$ & $\begin{array}{c}\text { Trash } \\
\text { presence }\end{array}$ & Habitat type & $\begin{array}{c}\text { Number } \\
\text { of trees }\end{array}$ & $\begin{array}{c}\text { Canopy } \\
\text { cover (\%) }\end{array}$ & $\begin{array}{c}\text { Water salinity } \\
\text { (ppt) }\end{array}$ & $\begin{array}{c}\text { No. of bird } \\
\text { species }\end{array}$ & $\begin{array}{c}\text { Total } \\
\text { Individuals }\end{array}$ \\
\hline 1 & Present & Mangrove forest & 16 & 35.84 & 10 & 9 & 17 \\
\hline 2 & Absent & Mangrove-fishpond & 14 & 19.37 & 31 & 9 & 18 \\
\hline 3 & Present & Mangrove-fishpond & 12 & 18.48 & 31 & 6 & 8 \\
\hline 4 & Present & Settlement & 4 & 15.97 & 30 & 4 & 6 \\
\hline 5 & Present & Settlement & 5 & 13.04 & 32 & 7 & 15 \\
\hline 6 & Present & Settlement & 6 & 15.43 & 21 & 4 & 7 \\
\hline 7 & Absent & Fishpond & 1 & 3.59 & 30 & 5 & 9 \\
\hline 8 & Absent & Fishpond & 5 & 8.61 & 30 & 4 & 6 \\
\hline 9 & Absent & Fishpond & 1 & 2.03 & 29 & 4 & 8 \\
\hline 10 & Absent & Fishpond & 9 & 15.24 & 27 & 7 & 18 \\
\hline 11 & Present & Mangrove forest & 4 & 21.5 & 29 & 5 & 6 \\
\hline 12 & Present & Mangrove-fishpond & 21 & 25.16 & 30 & 5 & 7 \\
\hline 13 & Absent & Mangrove-fishpond & 24 & 24.23 & 29 & 5 & 12 \\
\hline \multicolumn{4}{|c|}{ Standard Deviations (SD) } & 8.76 & 5.72 & & \\
\hline \multicolumn{4}{|l|}{ Average } & 16.81 & 27.61 & 6 & 10.54 \\
\hline \multicolumn{4}{|c|}{ Average fishpond } & 7.37 & 29.00 & 5 & 10.25 \\
\hline \multicolumn{4}{|c|}{ Average Mangrove forest } & 28.67 & 19.50 & 7 & 11.50 \\
\hline \multicolumn{4}{|c|}{ Average mangrove fishpond } & 21.81 & 30.25 & 6 & 11.25 \\
\hline \multicolumn{4}{|c|}{ Average settlement } & 14.81 & 27.67 & 5 & 9.33 \\
\hline
\end{tabular}

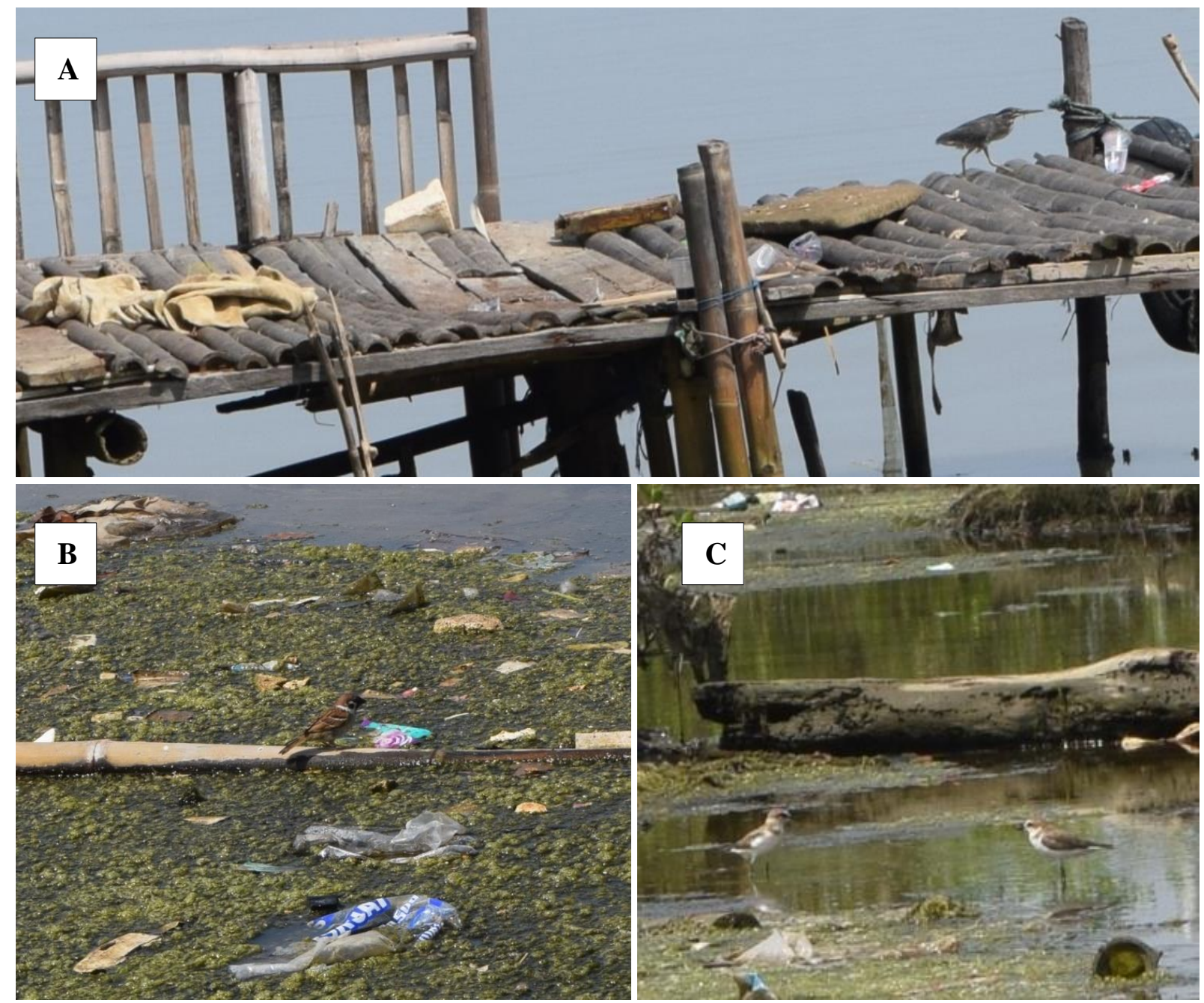

Figure 6. A. The Striated heron (Butorides striatus), B. The Eurasian Sparrow (Passer montanus), C. A pair of Javan plover (Charadrius javanicus) were foraging around the waste-contaminated location 
The path analysis suggested that the regression coefficient of organic waste on bird abundance was positive $(0.528)$, while for inorganic waste the regression coefficient was negative $(-0.176)$. Similar to the previous Spearman rank correlation analysis, these results suggested that organic waste increased bird abundance, while inorganic waste tended to decrease it,. This was consistent with previous studies that reported organic waste increased the abundance of some bird species while inorganic waste decreased the bird abundance (Zhang et al. 2015; Plaza and Lambertucci 2017).

Based on the results, specialist birds were rarely found in habitats contaminated with waste because specialist birds tend to occupy higher-quality habitats. This was consistent with previous studies that showed a decline of specialist-bird abundance in disturbed habitats (Sica et al. 2018). Further research needs to be carried out to explain the tolerance limits of specialist bird species to environmental disturbances, particularly to waste. Moreover, the presence of birds near the trash often occurred in higher canopy cover in mangrove forest habitats, especially for larger birds. This is because larger birds such as E. alba and E. sacra often use tree canopy for nesting, perching, and other activities in a colony. In this way, the trees act as a buffer preventing direct contact between birds and trash. However, sometimes E. alba is also found foraging around the trash.

Concurrently, several other species such as Ardeola sp. and Butorides sp. were more often found in terrestrial. In addition, smaller birds like the Eurasian sparrow and Javan plover were likely to be in habitats with more open canopies such as settlements (Figure 6). Small birds are more tolerant of residential habitats occupied by humans because smaller birds can fly with high acceleration and better maneuverability, thus avoiding predators (in this case: humans) from a closer distance (Weston et al. 2012; Tätte et al. 2018). Hence, the risk of waste exposure for small birds is high because human activities in the settlement produce new waste every day. Better management of habitat is therefore important to support these birds.

\section{The impact of waste on the bird abundance in Muara Gembong}

The Spearman test showed that 24 bird species had a negative correlation with inorganic waste, although only 3 species were significantly affected. The findings in the field indicated that the presence of inorganic waste in Muara Gembong can significantly reduce the abundance of bird species in the long term because inorganic waste changes the characteristics of bird habitat. Covering the surface water (Ryan 2018; Tan et al. 2012), inorganic waste stranded and buried can change the water flow and sedimentation disrupting particular food chains such as food sources for birds (Sklar and Browder 1998).

Our findings in the field showed that the salinity at observation point 1 (the point with the highest waste concentration) is only 10 ppt. Point 1 which was mangrove forest, was the point closest to the high seas with the highest trash present. Mangrove forests retained more garbage than other habitats as the garbage was trapped among the roots (Ivar do Sul et al. 2014). Inorganic waste may block the tidal flow of water which results in disrupting the balance of chemical substances in water, including salinity. Changes in salinity at a certain limit can cause mangrove mortality because it is not suitable for its survival. Although mangroves can grow well in a salinity range of 10-30 ppt (Hilmi et al. 2017), better management of the area should be improved particularly because the highest species richness of birds was recorded at point 1 .

Furthermore, inorganic waste can significantly decrease mangrove survival by increase leaf loss and deteriorate the mangrove stands (van Bijsterveldt et al. 2021). Moreover, the mangrove respiratory roots are being buried in the piles of inorganic waste, leading the mangrove to death (Ivar do Sul et al. 2014). This is consistent with findings in the field that showed piles of trash covered the pneumatophores and seemed to prevent the growth of new plants. As a result, there was small-scale deforestation of mangrove forests in areas covered with trash.

Even though trash cleaning was done at observation point 1 in August 2019 (Wulandari et al. 2019), that area was refilled within less than a year. If the cleaning activity is not carried out regularly, the accumulation of waste will increase and lead to widespread deforestation. The degradation of mangrove forests will accelerate environmental damage due to abrasion because one of the mangrove forest functions is as a barrier to sea waves (Husrin et al. 2012).

In conclusion, there were at least 26 species of birds in Muara Gembong that were found near the trash and 24 bird species have a negative correlation with inorganic waste, although only 3 species are significantly affected. The existence of inorganic waste in Muara Gembong can significantly reduce the abundance of bird species in the long term because the pile of inorganic waste causes damage to the mangrove forest, which is a bird habitat. As an important habitat for waterbirds, waste management in Muara Gembong needs to be considered more seriously.

\section{ACKNOWLEDGEMENTS}

This research was funded by the Directorate for Research and Community Service of Universitas Indonesia (DRPM UI) of grant research PUTI Q2 (NKB1659/UN2.RST/HKP.05.00/2020).

\section{REFERENCES}

Annorbah NN, Holbech LH. 2012. Relative abundance, agonistic behaviour, and resource partitioning among three scavenging bird species in Ghana. Malimbus 34 (34): 1-8.

Aziz AA, Phinn S, Dargusch P. 2015. Investigating the decline of ecosystem services in a production mangrove forest using Landsat and Object-based Image Analysis. Estuar Coast Shelf Sci 164: 353366. DOI: $10.1016 /$ j.ecss.2015.07.047 
Bibby CJ, Jones M, Marsden SJ, Sozer R, Nijman V, Shannaz J. 2000. Expedition Field Technique: Bird Surveys. Royal Geographical Society, London.

BirdLife International. 2020. Important Bird Areas factsheet: Muara Gembong-Tanjung Sedari. BirdLife International-Indonesian Program, Bogor.

Chawaka SN, Mereta ST, Goethals PLM, Lens L, Boets P. 2017. Effect of human-induced environmental changes on bird diversity and abundance in Natural Wetlands of Southwest Ethiopia. Waterbirds 40 (2): 129-143. DOI: 10.1675/063.040.0205.

Codina-García M, Militão T, Moreno J, González-Solís J. 2013. Plastic debris in Mediterranean seabirds. Mar Pollut Bull 77: 220-226. DOI: 10.1016/j.marpolbul.2013.10.002.

Durães R, Carrasco L, Smith TB, Karubian J. 2013. Effects of forest disturbance and habitat loss on avian communities in a Neotropical biodiversity hotspot. Biol Conserv 166: 203-211. DOI: 10.1016/j.biocon.2013.07.007.

Hilmi E, Kusmana C, Suhendang E, Iskandar. 2017. Correlation analysis between Seawater Intrusion and Mangrove Greenbelt. Indones J For Res 4 (2): 151-168. DOI:10.20886/ijfr.2017.4.2.151-168.

Husrin S, Strusińska A, Oumeraci H. 2012. Experimental study on tsunami attenuation by mangrove forest. Earth Planets Space 64 (10): 973-989. DOI: $10.5047 /$ eps.2011.11.008.

Ivar do Sul, J. A., Costa, M. F., Silva-Cavalcanti, J. S., \& Araújo, M. C. B. 2014. Plastic debris retention and exportation by a mangrove forest patch. Marine Pollution Bulletin, 78 (1-2): 252-257. DOI 10.1016/j.marpolbul.2013.11.011

Jurinovic L, Savic V, Balenovic M, Lisicic D, Lucic V. 2014. Virological and serological investigation of avian influenza in black-headed gulls captured on a rubbish dump in Zagreb, Croatia. Vet Arh 84 (5): 521528.

Lippiatt S, Opfer S, Arthur C. 2013. Marine Debris Monitoring and Assessment. NOAA Technical Memorandum NOS-OR \& R-46. NOAA Marine Debris Division, United States.

Liu J, Liang J, Yuan X, Zeng G, Yuan Y, Wu H, Huang X, Liu J, Hua S Li F, Li X. 2015. An integrated model for assessing heavy metal exposure risk to migratory birds in wetland ecosystem: A case study in Dongting Lake Wetland, China. Chemosphere 135: 14-19. DOI: 10.1016/j.chemosphere.2015.03.053.

MacKinnon J, Phillips K, Balen BV. 2010. A Field Guide to the Birds of Borneo, Sumatra, Java and Bali. Oxford University Press, UK.

Plaza P, Lambertucci S. 2017. How are garbage dumps impacting vertebrates, demography, health, and conservation? Glob Ecol Conserv 12: 9-20. DOI: 10.1016/j.gecco.2017.08.002.

Renken RC, Thompson JA, Maccarone AD. 2016. Factors affecting foraging microhabitat selection by wading birds at an artificial weir. Waterbirds 39 (4): 422-425. DOI: 10.1675/063.039.0413

Ryan, P. G. 2018. Entanglement of birds in plastics and other synthetic materials. Marine Pollution Bulletin, 135: 159-164. DOI: 10.1016/j.marpolbul.2018.06.057

Sica YV, Gavier-Pizarro GI, Pidgeon AM, Travaini A, Bustamante J, Radeloff VC, Quintana RD. 2018. Changes in bird assemblages in a wetland ecosystem after 14 years of intensified cattle farming. Austral Ecol 43: 786-797. DOI: 10.1111/aec.12621.

Sitanggang FI, Budiman MAK, Afandy A. 2020. Bird diversity: The potential of avitourism reserves for bird conservation in Curup Tenang, South Sumatera, Indonesia. Biodjati 5 (2): 249-258. DOI: 10.15575/biodjati.v5i2.9537.

Steigerwald EC, José-Manuel I, Payo-Payo A, Tavecchia G. 2015. Effects of decreased anthropogenic food availability on an opportunistic gull: Evidence for a size-mediated response in breeding females. Ibis 157 (3): 439-448. DOI: 10.1111/ibi.12252

Sklar FH, Browder JA. 1998. Coastal environmental impacts brought about by alterations to freshwater flow in the Gulf of Mexico. Environ Manag 22 (4): 547-562. DOI: 10.1007/s002679900127.

Tan AM, Zhao SX, Ye FY. 2012. Plastics-a formidable threat to unique biodiversity of Pichavaram mangroves. Curr Sci 103 (11): 1262

Tätte K, Møller AP, Mänd R. 2018. Towards an integrated view of escape decisions in birds: relation between flight initiation distance and distance fled. Anim Behav 136: 75-86. DOI: 10.1016/j.anbehav.2017.12.008.

Torres-Mura JC, Lemus ML, Hertel F. 2015. Plastic material in the diet of the Turkey vulture (Cathartes aura) in the Atacama Desert, Chile. Wilson J Ornithol 127 (1): 134-138. DOI: 10.1676/14-107.1.

van Bijsterveldt CEJ, van Wesenbeeck BK, Ramadhani S, Raven OV, van Gool FE, Pribadi R, Bouma TJ. 2021. Does plastic waste kill mangroves? A field experiment to assess the impact of macro plastics on mangrove growth, stress response and survival. Sci Total Environ 756: 143826. DOI: 10.1016/j.scitotenv.2020.143826.

Viljoen JMM, Schenck CJ, Volschenk L, Blaauw PF, Grobler L. 2021. Household waste management practices and challenges in a Rural Remote Town in the Hantam Municipality in the Northern Cape, South Africa. Sustainability 2021 (13): 5903. DOI: 10.3390/su13115903.

Weston MA, McLeod EM, Blumstein DT, Guay P-J. 2012. A review of flight-initiation distances and their application to managing disturbance to Australian birds. Emu - Austral Ornithol 112 (4): 269286. DOI: 10.1071/MU12026.

Wulandari YP, Raysina N, Muningsih D. 2019. Impact studies uf mangrove protector innovation in Mangrove Ecotourism Pantai Mekar Village. Jurnal Resolusi Konflik, CSR and Pemberdayaan (CARE) 4 (1): 43-50. [Indonesian]

Xiao C, Ye J, Esteves RM, Rong C. 2015. Using Spearman's correlation coefficients for exploratory data analysis on big dataset: Using Spearman's Correlation Coefficients for exploratory data analysis. Concurr Comput 28 (14): 3866-3878. DOI: 10.1002/cpe.3745.

Zhang Q, Wu J, Sun Y, Zhang M, Mai B, Mo L. 2015. Do bird assemblages predict susceptibility by e-waste pollution? A comparative study based on species and guild-dependent responses in China agroecosystems. PLoS ONE 10 (3): e0122264. DOI: 10.1371/journal.pone.0122264.

Zhou B, Liu J, Liang W. 2020. Breeding in a noisy world: Attraction to urban arterial roads and preference for nest-sites by the Scalybreasted munia (Lonchura punctulata). Glob Ecol Conserv 22: e00987. DOI: 10.1016/j.gecco.2020.e00987. 